\title{
Juridical Review Of Nominee Agreement In Land Of Tenure Property Rights Under The Book Of Civil Law And Agraria
}

\begin{abstract}
Indah Esti Cahyani ${ }^{1}$, M Farid Amirullah ${ }^{2}$ and Aryani Witasari ${ }^{3}$
Abstract. Nominee agreement is an agreement made between someone who by law can not be the subject of rights to certain lands (property rights), in this case that foreigners (WNA) and Indonesian Citizen (citizen), with the intention that the foreigners can master land de facto property rights, but legal-formal (de jure) land property rights are assigned to his Indonesian citizen. The purpose of this paper isto assess the position of the nominee agreement in Indonesia's legal system and the legal consequences arising in terms of the draft Civil Code and the Law on Agrarian. Agreement is an agreement unnamed nominee made based on the principle of freedom of contract and good faith of the parties. However, it should be noted that the law prohibits foreigners make agreements / related statement stock wealth / property (land) for and on behalf of others, sehingga the legal consequences of the agreement is the nominee of the agreement is not legally enforceable because the agreement was made on a false causa.

Keywords: Nominee Agreement; Property Rights; Foreigners.
\end{abstract}

\section{Introduction}

Land is one of the components of the ecosystem that is essential for human survival and also as a major factor in any development activity. Human linkages with land also advanced by Jade Gouw Siong ${ }^{4}$ which says that: "The land is very closely related to human life. Each person would need the land, even not only in his life, for human matipun still need a piece of land. "

Reflections on the land has strategic significance, because it contains not only the physical aspect but also the social, economic, cultural, and even political, as well as defense, security and law ${ }^{5}$, Man's relationship with a powerful ground demanding legal protection so that people can exercise their rights safely. Legal protection and land policy in Indonesia reference contained in Article 33 paragraph (3) NRI Constitution of 1945 states:"Earth and water and natural resources contained therein controlled by the state and used for the greatest prosperity of the people".

Further embodiments legal relationship between humans and the land stipulated in Act No.5 of 1960 About the Basic Regulation of Agrarian, otherwise known as the Basic Agrarian Law (BAL). The new agrarian law is based on the provisions of customary law, because customary law is the law of the indigenous people of Indonesia ${ }^{6}$,

Regarding the subject that can be given and the right to land, then in accordance with the principle of nationality listed in the BAL, specified in Article 9 paragraph (1) which states that only Indonesian citizen to have a complete break with the earth, water, and space. In

\footnotetext{
1 Master of Notary's Student, Faculty of Law, Universitas Islam Sultan Agung email: indahesticahyani@gmail.com.

2 Students of Master of Law, Faculty of Law, Universitas Islam Sultan Agung email farid ocre@yahoo.co.id

3 Lecture of Faculty of Law UNISSULA

${ }^{4}$ Gow Jade Siong 2000 Tafsiran Undang-Undang Pokok Agraria Keng Po Jakarta p.46.

${ }^{5}$ FX Sumarja 2012 Problematika Kepemilikan Tanah Bagi Orang Asing-Sebuah Tinjauan Yuridis Filosofis indepth Publishing Bandar Lampung p.V.

${ }^{6}$ Boedi Harsono 2008 Hukum Agraria Indonesia : Sejarah Pembentukan Undang-Undang Pokok Agraria Isi dan Pelaksanaannya Djambatan Jakarta p. 139.
} 
the explanation of the article is just an Indonesian citizen who can be the subject of property rights.

Moreover, in the BAL is set also forms of land ownership by foreigners (WNA) may be of use rights and lease rights set forth in Article 42 sub b and Article 45 sub b. But the ownership of land by foreigners (WNA) is clearly prohibited by the state. Breadth authority contained in land ownership, while foreigners are not allowed to have it, many ways in the travel by foreign citizens to be able to master the freehold land in Indonesia. Moreover, as the political changes in the new order, much of the land it controlled by a group of foreign investors ${ }^{7}$, Conditions that appear on the various regulations issued by the government, such as the deregulation policy in October 1993 that simplifies the process of granting Hak Guna Usaha (HGU) and the Right to Build (HGB) ${ }^{8}$,

In fact, since 1953, in the opinion of S. Poerwopranoto that for a ban on selling land to foreigners is still there, of course foreigners will try to break them, for example by using the intercession of Citizen Indonesia. ${ }^{9}$ Through nominee agreements, foreigners may have a freehold land in Indonesia by registering the land in the name of Indonesian citizen designated as nominee.

Nominee agreement totally unknown in the Indonesian legal system, especially in Indonesia Contract Law, and there is no regulation specifically and distinctly, so that it can be said implies that empty or empty norm. The emergence of a nominee agreement is a form of legal imperfection in Indonesia which is then used by foreign citizens for their interest. Based on the foregoing, this article aims to examine the position of a nominee agreement in Indonesia's legal system and the legal consequences arising in terms of the draft Civil Code and the Law on Agrarian.

\section{Discussion}

\subsection{Position Nominee Agreement In Indonesian Legal System}

The use of nominee (ostensibly) in fact is the embodiment of the existence of an engagement. Article 1233 Book of the Law of Civil Law (hereinafter referred to as the Civil Code) says "every engagement is born good for approval, either because of legislation". Furthermore, Article 1234 states "each engagement is to give something, to do something and not do anything". so thatcontracts are legally valid as a law for them ${ }^{10}$,

Legal agreements in Indonesia adheres to the principle of freedom in terms of making the agreement (beginsel der contracts vrijheid). This principle can be inferred from Article 1338 of the Civil Code stating that all agreements made legally valid as law for those who make it. Is actually meant by that article is nothing other than a statement that any agreement binding on both parties. But from this article then it can be deduced that the people freely to make any agreements of origin does not violate public order or morality. People can not only conveniently for producing any agreement, even in general is also allowed to waive the regulations contained in the Civil Code. The system is commonly

\footnotetext{
${ }^{7}$ Gunawan Wiradi 2001 Prinsip-Prinsip Reforma Agraria Jalan Penghidupan dan Kemakmuran Rakyat Lapera Pustaka Utama Yogyakarta p.163.

8 Maria SW Sumardjono 2009 Tanah Dalam Perspektif Hak Ekonomi Sosial dan Budaya Jakarta: Kompas book p. 23.

${ }^{9}$ https://kependudukanpemdadiy.files.wordpress.com/2010/09/laporan-triwulan-iiidatakependudukan-tahun-2012-provinsi-diy-aksen.pdf accessed on March 29, 2018.

${ }_{10}$ Muhammad Syaifuddin 2012 Hukum Kontrak (Memahami Kontrak dalam Perspektif Filsafat Teori Dogmatik dan Praktik Hukum Seri Pengayaan Hukum Perikatan CV Mandar Maju Bandung p. 82.
} 
known as an open system (openbaar system) ${ }^{11}$

Furthermore, the agreement is said to be valid if it satisfies the provisions of Article 1320 as follows:

(1) The agreement will (consesus, agreement);

(2) Skills do so by law (capacity);

(3) A particular object or subject that is clear and justified by law; and

(4) Causes permissible, lawful and legal.

In the article has not regulated in detail on the subject of the law in question. Only a competent law alone. National land law itself, as mentioned previously ruled that only Indonesian citizen is entitled to have the freehold land in Indonesia. To get around this, then made a nominee agreement made between foreigners with Indonesian citizens. By using a nominee agreement, foreigners can own land in the form of property rights in Indonesia by registering the land in the name of Indonesian citizen designated as nominee. ${ }^{12}$ Implicitly, a nominee agreement has the following elements:

- Authorization agreement between two parties, namely as an endorser and endorsee as a nominee, which is based on the belief of the nominee;

- Authorization granted is specific to the type of legal action is limited;

- nominee act as if (as If) as a representative of the beneficial owner in front of the law ${ }^{13}$, At first glance it appears that a nominee agreement with power of attorney is generally the same as both require parties who act as an endorser and endorsee. However, when examined closely, both of which are similar but not the same. Nominee agreement of nature is equal to the reciprocal agreement, which the parties have an obligation to meet the achievement of each party listed in the agreement. This is due to the power contained in the agreement are more lastgeving nominee, where the power is given more emphasis on the provision of command load to the recipient authority to carry out the achievements of the agreement.

Nominee Agreement is one of a kind Innominaat Agreement, that agreement is not recognized in the Civil Code but arise, grow and develop in society. Under the Civil Code, Nominee Agreement shall be subject to the provisions of the law of treaties in Book III of the Civil Code About Engagement.

Nominee Agreement totally unknown in the Indonesian legal system, especially in Indonesia Contract Law, and there is no regulation specifically and distinctly, so that it can be said implies that empty or empty norm. Nominee Agreement emergence of a form of legal imperfection in Indonesia, which was then used by foreign citizens for their own interests.

\subsection{As a result of Nominee Agreement Law in Case of Land Ownership}

In general, legal entities, both Indonesian legal entities and foreign legal entities and foreign citizens are only allowed to control and use of land, if the right was expressly allowed by the relevant regulations. Clauses in the Law that allows for it is Article $30 \mathrm{BAL}$ for legal entities, namely: "only a legal entity established under Indonesian law and domiciled in Indonesia, which may be the holder of leasehold and Broking". As for foreign

\footnotetext{
${ }^{11}$ Kartini Muljadi and Gunawan Widjaja 2003 Perikatan Yang Lahir Dari Perjanjian Raja Grafindo Persada Jakarta p. 46.

12 S.Poerwopranoto 1945 Penuntun Tentang Hukum Tanah Sinar Grafika Jakarta p. 48.

13 Andina Damayanti Saputri 2015 Perjanjian Nominee Dalam KepemilikanTanah Bagi Warga Negara Asing Berkedudukan di Indonesia (Studi Putusan Pengadilan Tinggi Nomor: 12/PDT/2014/PT.DPS https://media.neliti.com/media/publications/213115-perjanjian-nomineedalam-kepemilikan-tan.pdf Accessed on March 29, 2018
} 
citizens and foreign legal entities are given the appropriate rights set out in Articles 41, 42, 45, and Article 55 BAL. BAL Article 42 stipulates that to have the right to use is:

- Indonesian citizens

- The foreigners domiciled in Indonesia

- Legal entities established under Indonesian law and domiciled in Indonesia

- Foreign legal entity with offices in Indonesia.

According to Article 26 paragraph (2) of the BAL, Hak to foreigners is prohibited and a violation of this chapter containing sanctions null and void. However, BAL is not close at all occasions foreigners and foreign legal entities to have land rights in Indonesia.

According Boedi Harsono, the rights of individuals are given the right to wear in the sense of control, use and / or taking certain benefits, such as rights to land which will remain as the Property. Can be seen if by Boedi Harsono rights to control land rights is still in the form of property rights, the foreign citizen can not be said to dominate or take these benefits, because foreigners can only use use rights and the right to lease only ${ }^{14}$,

According to Subekti: "The agreement made between foreigners and Indonesian citizen was based on a false causa, the agreement made by pretending to hide causa which is not allowed". ${ }^{15}$

Nominee agreement subjective qualify but clearly violates a treaty objective conditions of an agreement for causanya or why is counterfeit or illicit because the agreement resulted in the violation of Article 26 paragraph (2) BAL. Further down in Article 1335 Book of the Law of Civil Law (Civil Code) proposed that an agreement be made with a causa counterfeit or illicit do not have the force of law, also under Article 1337 of the Civil Code states that any reason is prohibited, to the extent prohibited by legislation or if contrary to morality or public order.

Therefore, the nominee agreement agreement is invalid because it violated the provisions of the legislation, especially in this case is the provision of Article 21 paragraph (1) and Article 26 paragraph (2) of the BAL, the nominee agreement is agreement void from the beginning, because the nominee agreement was made illegally, so it does not have binding legal force. This is supported by the issuance of Act No.25 of 2007 on Investment, where Article 33 is formulated as follows:

(1) Investments in domestic and foreign investors making an investment in the form of a limited liability company are prohibited from making agreements and / or a statement confirming that the ownership of shares in a limited liability company and on behalf of others; and

(2) In terms of domestic investors and foreign investors make an agreement and / or the declaration referred to in paragraph (1), agreements and / or the statement was declared null and void.

Practice nominee is already often used to manipulate the ownership of shares in the company. Borrowing the name is also used for land ownership in Indonesia. With the issuance of Act No.25 of 2007, share ownership or land use this nominee has been expressly prohibited and consequently void.

When analyzed there is harmonization of legislation among UUPM with the provisions of Articles 1335 and 1337 of the Civil Code, which is lex Market Law prohibits the use nominee agreement of the shares resulting void if the agreement was made, in other words, the agreement has never been considered, rights and obligations arising from

\footnotetext{
${ }^{14}$ Boedi Harsono 2007 Hukum Agraria Indonesia Sinar Grafika Jakarta p. 27-28.

${ }^{15}$ Subekti 1992 Bunga Rampai IImu Hukum Alumni Bandung p. 137.
} 
Volume 5 Issue 2, June 2018

these agreements are also considered to be no. ${ }^{16}$

\section{Closing}

\subsection{Conclusion}

- Nominee agreement totally unknown in the Indonesian legal system, especially in Indonesia Contract Law, and there is no regulation specifically and distinctly, so that it can be said implies that empty or empty norm. Basically agreement to borrow the name (nominee) aims to avoid the prohibition Foreigners have the right to land as stipulated in Article 21 paragraph (1) BAL.

- Akibat law to the treaty nominee in terms of land ownership in Indonesia is the agreement has no legal force and become null and void because the agreement was made on causa false and violate the provisions of Article 26 paragraph (2) BAL and Article 33 paragraph (1), ( 2) Capital Market Law.

\subsection{Suggestion}

- The government should review the relevant regulations on agreements involving foreign citizens in order to create legal certainty and does not overlap with the legislation in practice.

- Notary should prioritize the elements of caution and apply the law in accordance with the legislation in force. Educate and provide information through legal counseling to the penghadap either the citizen or foreigner will be poured into a deed so as to create legal protection and legal certainty through legal products notarial deed.

- For society in general should be more prudent in legal actions, especially in land sales involving foreign citizens.

\section{References}

[1] Andina Damayanti Saputri 2015 Perjanjian Nominee Dalam KepemilikanTanah Bagi Warga Negara Asing Berkedudukan di Indonesia (Studi Putusan Pengadilan Tinggi Nomor: 12/PDT/2014/PT.DPS https://media.neliti.com/media/publications/213115perjanjian-nominee-dalam-kepemilikan-tan.pdf Accessed on March 29, 2018

[2] Boedi Harsono 2007 Hukum Agraria Indonesia Sinar Grafika Jakarta.

[3] Boedi Harsono 2008 Hukum Agraria Indonesia : Sejarah Pembentukan UndangUndang Pokok Agraria Isi dan Pelaksanaannya Djambatan Jakarta.

[4] FX Sumarja 2012 Problematika Kepemilikan Tanah Bagi Orang Asing-Sebuah Tinjauan Yuridis Filosofis indepth Publishing Bandar Lampung.

[5] Gow Jade Siong 2000 Tafsiran Undang-Undang Pokok Agraria Keng Po Jakarta.

[6] Gunawan Wiradi 2001 Prinsip-Prinsip Reforma Agraria Jalan Penghidupan dan Kemakmuran Rakyat Lapera Pustaka Utama Yogyakarta.

[7] https://kependudukanpemdadiy.files.wordpress.com/2010/09/laporan-triwulan-iiidatakependudukan-tahun-2012-provinsi-diy-aksen.pdf accessed on 29 April 2018.

[8] Joko Prabowo 2017 Analisis Yuridis Terhadap Perjanjian Nominee Atas Kepemilikan Saham Pada Perseroan Terbatas (Studi Putusan Pengadilan Negeri Medan Nomor : 1269/Pid.B/2013/PN Mdn. dan Putusan Mahkamah Agung Nomor 3007 K/Pdt./2014)

\footnotetext{
${ }^{16}$ Joko Prabowo 2017 Analisis Yuridis Terhadap Perjanjian Nominee Atas Kepemilikan Saham Pada Perseroan Terbatas (Studi Putusan Pengadilan Negeri Medan Nomor : 1269/Pid.B/2013/PN Mdn. dan Putusan Mahkamah Agung Nomor 3007 K/Pdt./2014) p 95. http://repositori.usu.ac.id/bitstream/handle/123456789/912/157011180.pdf?sequence=1\&isAllo wed=y Accessed on March 29, 2018.
} 
http://repositori.usu.ac.id/bitstream/handle/123456789/912/157011180.pdf?seque nce $=1$ \&isAllowed =y Accessed on March 29, 2018.

[9] Joko Prabowo 2017 Juridical Analysis Of Top Nominee Agreement On Shareholding Company Limited (Study of the Medan District Court Decision No. 1269 / Pid.B / 2013 / PN Mdn and the Supreme Court Decision No. 3007 K / Pdt. / 2014).

[10]Kartini Muljadi and Gunawan Widjaja 2003 Perikatan Yang Lahir Dari Perjanjian Raja Grafindo Persada Jakarta.

[11]Maria SW Sumardjono 2009 Tanah Dalam Perspektif Hak Ekonomi Sosial dan Budaya Jakarta: Kompas book.

[12] Muhammad Syaifuddin 2012 Hukum Kontrak (Memahami Kontrak dalam Perspektif Filsafat Teori Dogmatik dan Praktik Hukum Seri Pengayaan Hukum Perikatan CV Mandar Maju Bandung.

[13]S.Poerwopranoto 1945 Penuntun Tentang Hukum Tanah Sinar Grafika Jakarta.

[14]Subekti 1992 Bunga Rampai Ilmu Hukum Alumni Bandung. 